\title{
Is Higher Efficacy Always at the Price of More Side Effects during Chemotherapy?
}

\author{
Brigitte Mlineritsch
}

Third Medical Department with Hematology, Medical Oncology, Hemostaseology, Infectious Disease and Rheumatology, Private Medical University Salzburg, Austria

\section{Key Words}

Breast cancer . Chemotherapy: dose-dense, tailored . Efficacy · Toxicity · Dose intensification .

\section{Summary}

Breast cancer remains the most prevalent cancer diagnosed in women worldwide. The number of effective treatments for breast cancer is on the rise, however, the benefit from specific treatments to individual patients and the adverse events experienced vary considerably. Efficacy and safety of anticancer therapies may depend on tumor, treatment, and host characteristics. Advances in the adjuvant chemotherapy of operable breast cancer have come from the introduction of effective agents and the application of the principles of combination chemotherapy. Attempts to advance these principles by substantial escalation of drug dosage have proven unsuccessful with a potentially higher rate of side effects. Another concept to increase efficacy is dose density, the administration of drugs with shortened intertreatment interval, and sequential therapy. The dose-dense concept improved clinical outcome significantly and was not accompanied by an increase in toxicity.

\section{Introduction}

Breast cancer is the most common malignancy in women in industrialized countries, and the leading cause of death among women aged 40-79 years [1]. Adjuvant combination chemo-

\section{Schlüsselwörter}

Mammakarzinom - Chemotherapie: dosisdichte, individuell angepasste . Wirksamkeit . Nebenwirkungen . Dosisintensivierung

\section{Zusammenfassung}

Das Mammakarzinom ist nach wie vor das häufigste Karzinom der Frau weltweit. Die Zahl der wirksamen Therapien steigt, jedoch ist der Gewinn von einzelnen Therapien und deren Nebenwirkungen für die individuelle Patientin sehr unterschiedlich. Wirksamkeit und Nebenwirkungen der Chemotherapie hängen von Charakteristika des Tumors, aber auch von Eigenheiten der Therapie und der Patientin ab. Fortschritte in der adjuvanten Chemotherapie des primär operablen Mammakarzinoms wurden durch die Einführung neuer Substanzen und durch die Verabreichung einer Kombinationschemotherapie erzielt. Versuche, diese Fortschritte durch Dosiseskalation zu verbessern, erwiesen sich als erfolglos mit beträchtlicher Zunahme der Nebenwirkungen. Ein anderer Weg, die Effektivität zu erhöhen, ist das Dosedense-Prinzip, in dem die Intervalle zwischen den Chemotherapien verkürzt werden, und die sequentielle Verabreichung der Zytostatika. Das Dose-dense-Prinzip erwies sich der konventionellen Verabreichung signifikant überlegen, ohne Zunahme der Nebenwirkungen.

therapy reduces the risk of relapse and death for patients with operable primary breast cancer. In an attempt to improve these results, various manipulations of dose and schedule of administration have been tested.

\section{KARGER}

Fax +497614520714

Information@Karger.de

www.karger.com (c) 2009 S. Karger GmbH, Freiburg 


\section{Dose Intensity}

The response to conventional doses of chemotherapy to treat breast cancer is dose-related. Dose intensification has generated great research interest over the last decades. The term dose-intensity was formulated as body size-adjusted dose divided by time [2]. Part of the appeal of dose intensity has been the experimental observation that efficacy can be increased for some agents by increasing the dose [3]. But clinical results did not match this prediction. Dose escalation of doxorubicin in the Henderson trial [4] did not suggest an advantage for doses of more than $60 \mathrm{mg} / \mathrm{m}^{2}$. However, this was not true for epirubicin. The French adjuvant study group [5] has demonstrated an absolute 5-year survival gain of $12 \%$ for patients receiving epirubicin at $100 \mathrm{mg} / \mathrm{m}^{2}$, compared with $50 \mathrm{mg} / \mathrm{m}^{2}$ in the FEC (5-fluorouracil, epirubicin, cyclophosphamide) regimen. The benefit of a higher epirubicin dose has also been demonstrated in another randomized epirubicin-containing adjuvant study by Piccart et al. [6]. For cyclophosphamide, intensifying dose levels over $2,400 \mathrm{mg} / \mathrm{m}^{2}$ did not substantialy improve outcome in reports of the NSABP B-22 and NSABP B-25 trials [7]. Moreover, the results from these studies indicate that higher doses of cyclophosphamide may increase the risk of secondary leukemia. The dose intensification for paclitaxel is less studied and was complicated by the duration of infusion. There seems to be an advantage for $175 \mathrm{mg} / \mathrm{m}^{2}$ when administered over $3 \mathrm{~h}$, and even higher doses may offer a small additional benefit [8]. The standard dose and administration of docetaxel is 100 $\mathrm{mg} / \mathrm{m}^{2}$ as a $1-\mathrm{h}$ infusion every third week. The dose-limiting toxicity is myelosuppression which is dose- but not scheduledependent. The French study PACS 01, comparing 3 cycles of $\mathrm{F}_{500} \mathrm{E}_{100} \mathrm{C}_{500}$ followed by 3 courses of docetaxel $100 \mathrm{mg} / \mathrm{m}^{2}$ revealed an overall survival gain compared with 6 courses of $\mathrm{F}_{500} \mathrm{E}_{100} \mathrm{C}_{500}$ [9].

The concept of dose intensification in breast cancer was developed at the Dana-Faber Cancer Institute by Dr. Emil Frei [10] who was the first to demonstrate that the cell kill effected by multiple alkylating agents had a step-dose-response correlation. Because most of the toxicity of these agents was to the bone marrow, one could administer these lethal doses only with autologous stem cell transplant, but at a considerable risk of treatment-related mortality [11]. Although several randomized studies suggested a reduction in recurrence risk among subsets of breast cancer patients, there has been no convincing evidence of a survival benefit of high-dose chemotherapy [12-16]. A randomized trial of Southwest Oncology Group 9623 compared intensive dose-dense with high-dose adjuvant chemotherapy for high-risk operable breast cancer, with no evidence that transplantation was superior to dosedense dose-escalated therapy. Transplantation was associated with increased toxicity and possible inferior outcome, although the hazard ratios were not significantly different from the dose-dense regimen [17].

Higher Efficacy Always at the Price of More Side Effects?

\section{Dose-Dense}

To overcome resistance, combination chemotherapy using several drugs simultaneously at full dosages or, where possible, in rapid alternation, was predicted to be superior and was clinically studied [18]. The lack of success with alternating therapy in breast cancer suggests that the underlying assumptions may be incorrect [19]. Human solid tumors do not grow exponentially, but in a Gompertzian pattern [20]. Tumor regrowth after subcurative therapy is rapid after each cycle of treatment, so eradication of disease is difficult even when all of the cells are sensitive to the drugs used. An alternative model to eradicate these cells is the dose-dense model. Dosedense treatments increase dose intensity not by increasing the dose, as with dose escalation, but by decreasing the time. Although dose intensity may be increased by dose escalation or by increasing dose density or by both, an advantage of dose density is that it should work even when the dose relationship for the agents being used is not rising steeply in the feasible dose range. Sequential therapy is by definition more dosedense than alternative regimens. Hudis et al. [21] reported a promising 4-year disease-free survival rate of $78 \%$ and an acceptable toxicity profile in women with high-risk node-positive breast cancer, who were treated in an adjuvant phase II study with both sequential dose-dense and dose-escalated paclitaxel, doxorubicin, and cyclophosphamide. The following Intergroup trial C9741 was a randomized adjuvant trial in women with node-positive breast cancer. The $2 \times 2$ factorial design compared single sequential-agent doxorubicin, paclitaxel, and cyclophosphamide to concurrent doxorubicin and cyclophosphamide followed by paclitaxel, delivered either every 2 weeks, dose-dense, with growth factor support, or every 3 weeks without growth factor support. The study results demonstrated that patients receiving dose-dense treatment experienced an improvement in disease-free and overall survival, however, there was no difference between sequential or concurrent drug administration. Toxicity was similar in both arms, however, there was an increase in red blood cell transfusions on the concurrent dose-dense arm, and grade 4 neutropenia was less common in the dose-dense treatment. Based on these results, dose-dense chemotherapy has become an approved regimen for the adjuvant treatment of node-positive breast cancer [22]. Another study from Germany found dose-dense, sequential epirubicin and paclitaxel to be superior to the combination of these agents given according to a standard 3-weekly schedule. This trial combined both dose intensity and dose density but did not control for total cumulative doses which were higher in the dose-dense arm [23]. Another German trial, presented by Jakisch et al. [24], found that a dose-dense doxorubicin-docetaxel regimen given for 4 cycles was inferior to a more conventional regimen of sequential doxorubicin/cyclophosphamide-docetaxel preoperative chemotherapy in terms of complete and pathologically complete responses, as well as breast conservation rates. 


\section{Tailored Chemotherapy}

Almost all cancer drugs are delivered according to body surface area and individually modulated doses. It is well established that this will not compensate for pharmacokinetic and pharmacodynamic variations of most cytostatics [25]. Body surface area-based dosage will therefore result in severe toxicity for some patients and no or minor toxicity for others. Five retrospective studies showed statistically significant worse outcome for patients with fewer side effects [26]. These retrospective observations have been further explored in 2 randomized studies, Scandinavian Breast Group (SBG) 9401 and 2001-1 study. Tailored FEC with granulocyte colony-stimulating factor (G-CSF) support resulted in a significantly improved relapse-free survival and fewer grade 3 and 4 toxicities compared with marrow-supported high-dose chemotherapy as adjuvant therapy in women with high-risk primary breast cancer in the SBG 9401 study [27] A major complication in the study was the high incidence of acute leukemia or myelodysplastic syndrome in the tailored arm with $3.6 \%$.

The concept of tailored therapy is more efficacy at the price of more side effects. In a cooperation between the Scandinavian Breast Cancer Group, the Austrian Breast and Colon Cancer Study Group, and the German Breast Group, a randomized study was started to investigate whether tailor- ing and dose densification is superior to a fixed-dose strategy without dose intensification. The 'Panther Trial' compares the use of dose-dense and tailored epirubicin/cyclophosphamide followed by dose-dense and tailored docetaxel with 3-weekly FEC followed by docetaxel in lymph node-positive or highrisk lymph node-negative breast cancer patients.

\section{Conclusion}

'Is higher efficacy always at the price of more side effects during chemotherapy?' - The answer must be 'Yes'. Only the dose-dense approach seems to have a marginal decrease of side effects combined with a superiority in efficacy. But more studies are needed to underline this assumption. Fore the future, microarrays as well as pharmacogenetic and pharmacogenomic technologies will be a rational basis for tailored therapy strategies based on individual tumor biological characteristics, aiming towards a more effective and selective therapy.

\section{Conflict of Interest}

The author did not provide a conflict of interest statement.

\section{References}

1 Jemal A, Siegel R, Ward E, Hao Y, Xu J, Murray T, Thun MJ: Cancer statistics, 2008. CA Cancer J Clin 2008;58:71-96.

2 Hryniuk W, Levine MN: Analysis of dose intensity for adjuvant chemotherapy trials in stage II breast cancer. J Clin Oncol 1986;4:1162-1170.

3 Skipper HE, Schabel FM Jr, Wilcox WS: Experimental evaluation of potential anticancer agents. xiii. on the criteria and kinetics associated with 'curability' of experimental leukemia. Cancer Chemother Rep 1964;35:1-111.

4 Henderson IC, Berry DA, Demetri GD, Cirrincione CT, Goldstein LJ, Martino S, Ingle JN, Cooper MR, Hayes DF, Tkaczuk KH, Fleming G, Holland JF, Duggan DB, Carpenter JT, Frei E, III, Schilsky RL, Wood WC, Muss HB, Norton L: Improved outcomes from adding sequential paclitaxel but not from escalating doxorubicin dose in an adjuvant chemotherapy regimen for patients with node-positive primary breast cancer. J Clin Oncol 2003;21:976-983.

$\checkmark 5$ French Adjuvant Study Group: Benefit of a highdose epirubicin regimen in adjuvant chemotherapy for node-positive breast cancer patients with poor prognostic factors: 5-year follow-up results of French Adjuvant Study Group 05 randomized trial. J Clin Oncol 2001;19:602-611.

6 Piccart MJ, Di Leo A, Beauduin M, Vindevoghel A, Michel J, Focan C, Tagnon A, Ries F, Gobert P, Finet C, Closon-Dejardin MT, Dufrane JP, Kerger J, Liebens F, Beauvois S, Bartholomeus S, Dolci S, Lobelle JP, Paesmans M, Nogaret JM: Phase III trial comparing two dose levels of epirubicin combined with cyclophosphamide, methotrexate, and fluorouracil in node-positive breast cancer. J Clin Oncol 2001;19:3103-3110.
7 Fisher B, Anderson S, Wickerham DL, DeCillis A, Dimitrov N, Mamounas E, Wolmark N, Pugh R, Atkins JN, Meyers FJ, Abramson N, Wolter J, Bornstein RS, Levy L, Romond EH, Caggiano V, Grimaldi M, Jochimsen P, Deckers P: Increased intensification and total dose of cyclophosphamide in a doxorubicin-cyclophosphamide regimen for the treatment of primary breast cancer: findings from National Surgical Adjuvant Breast and Bowel Project B-22. J Clin Oncol 1997;15:1858-1869.

8 Nabholtz JM, Gelmon K, Bontenbal M, Spielmann M, Catimel G, Conte P, Klaassen U, Namer M, Bonneterre J, Fumoleau P, Winograd B: Multicenter, randomized comparative study of two doses of paclitaxel in patients with metastatic breast cancer. J Clin Oncol 1996;14:1858-1867.

$\checkmark 9$ Roche H, Fumoleau P, Spielmann M, Canon JL, Delozier T, Serin D, Symann M, Kerbrat P, Soulie P, Eichler F, Viens P, Monnier A, Vindevoghel A, Campone M, Goudier MJ, Bonneterre J, Ferrero JM, Martin AL, Geneve J, Asselain B: Sequential adjuvant epirubicin-based and docetaxel chemotherapy for node-positive breast cancer patients: the FNCLCC PACS 01 Trial. J Clin Oncol 2006;24: 5664-5671.

10 Frei E, III, Teicher BA, Holden SA, Cathcart KN, Wang YY: Preclinical studies and clinical correlation of the effect of alkylating dose. Cancer Res 1988;48:6417-6423.

11 Peters WP, Stuart A, Klotman M, Gilbert C, Jones RB, Shpall EJ, Gockerman J, Bast RC, Jr., Moore JO: High-dose combination cyclophosphamide, cisplatin, and melphalan with autologous bone marrow support. A clinical and pharmacologic study. Cancer Chemother Pharmacol 1989;23:377-383.
12 Hortobagyi GN, Buzdar AU, Theriault RL, Valero V, Frye D, Booser DJ, Holmes FA, Giralt S, Khouri I, Andersson B, Gajewski JL, Rondon G, Smith TL, Singletary SE, Ames FC, Sneige N, Strom EA, McNeese MD, Deisseroth AB, Champlin RE: Randomized trial of high-dose chemotherapy and blood cell autografts for high-risk primary breast carcinoma. J Natl Cancer Inst 2000;92:225-233.

13 Roche H, Viens P, Biron P, Lotz JP, Asselain B: High-dose chemotherapy for breast cancer: the French PEGASE experience. Cancer Control 2003; 10:42-47.

14 Rodenhuis S, Richel DJ, van der Wall E, Schornagel JH, Baars JW, Koning CC, Peterse JL, Borger JH, Nooijen WJ, Bakx R, Dalesio O, Rutgers E: Randomised trial of high-dose chemotherapy and haemopoietic progenitor-cell support in operable breast cancer with extensive axillary lymph-node involvement. Lancet 1998;352:515-521.

15 Tallman MS, Gray R, Robert NJ, LeMaistre CF, Osborne CK, Vaughan WP, Gradishar WJ, Pisansky TM, Fetting J, Paietta E, Lazarus HM: Conventional adjuvant chemotherapy with or without high-dose chemotherapy and autologous stem-cell transplantation in high-risk breast cancer. N Engl J Med 2003;349:17-26.

16 Zander AR, Schmoor C, Kroger N, Kruger W, Mobus V, Frickhofen N, Metzner B, Berdel WE, Koenigsmann M, Thiel E, Wandt H, Possinger K, Kreienberg R, Schumacher M, Jonat W: Randomized trial of high-dose adjuvant chemotherapy with autologous hematopoietic stem-cell support versus standarddose chemotherapy in breast cancer patients with 10 or more positive lymph nodes: overall survival after 6 years of follow-up. Ann Oncol 2008;19:1082-1089. 
\17 Moore HC, Green SJ, Gralow JR, Bearman SI, Lew D, Barlow WE, Hudis C, Wolff AC, Ingle JN, Chew HK, Elias AD, Livingston RB, Martino S: Intensive dose-dense compared with high-dose adjuvant chemotherapy for high-risk operable breas cancer: Southwest Oncology Group/Intergroup study 9623. J Clin Oncol 2007;25:1677-1682.

18 Goldie JH, Coldman AJ, Gudauskas GA: Rationale for the use of alternating non-cross-resistant chemotherapy. Cancer Treat Rep 1982;66:439-449.

19 Bonadonna G, Zambetti M, Valagussa P: Sequential or alternating doxorubicin and CMF regimens in breast cancer with more than three positive nodes. Ten-year results. JAMA 1995;273:542-547.

20 Norton L: A Gompertzian model of human breast cancer growth. Cancer Res 1988;48:7067-7071.

-21 Hudis C, Seidman A, Baselga J, Raptis G, Lebwohl D, Gilewski T, Moynahan M, Sklarin N, Fennelly D, Crown JP, Surbone A, Uhlenhopp M, Riedel E, Yao TJ, Norton L: Sequential dose-dense doxorubicin, paclitaxel, and cyclophosphamide for resectable high-risk breast cancer: feasibility and efficacy. J Clin Oncol 1999;17:93-100.
22 Citron ML, Berry DA, Cirrincione C, Hudis C, Winer EP, Gradishar WJ, Davidson NE, Martino S, Livingston R, Ingle JN, Perez EA, Carpenter J, Hurd D, Holland JF, Smith BL, Sartor CI, Leung EH, Abrams J, Schilsky RL, Muss HB, Norton L: Randomized trial of dose-dense versus conventionally scheduled and sequential versus concurrent combination chemotherapy as postoperative adjuvant treatment of node-positive primary breast cancer: first report of Intergroup Trial C9741/Cancer and Leukemia Group B Trial 9741. J Clin Oncol 2003;21:1431-1439.

23 Untch M, Mobus V, Kuhn W, Muck BR, Thomssen C, Bauerfeind I, Harbeck N, Werner C, Lebeau A, Schneeweiss A, Kahlert S, von Koch F, Petry KU, Wallwiener D, Kreienberg R, Albert US, Luck HJ, Hinke A, Janicke F, Konecny GE: Intensive dosedense compared with conventionally scheduled preoperative chemotherapy for high-risk primary breast cancer. J Clin Oncol 2009; Epub ahead of print.
4 Jackisch C, von Minckwitz G, Eidtmann H, Costa SD, Raab G, Blohmer JU, Schutte M, Gerber B, Merkle E, Gademann G, Lampe D, Hilfrich J, Tulusan AH, Caputo A, Kaufmann M: Dose-dense biweekly doxorubicin/docetaxel versus sequential neoadjuvant chemotherapy with doxorubicin/cyclophosphamide/docetaxel in operable breast cancer: second interim analysis. Clin Breast Cancer 2002;3: 276-280.

25 Felici A, Verweij J, Sparreboom A: Dosing strategies for anticancer drugs: the good, the bad and body-surface area. Eur J Cancer 2002;38:1677-1684.

26 Saarto T, Blomqvist C, Rissanen P, Auvinen A, Elomaa I: Haematological toxicity: a marker of adjuvant chemotherapy efficacy in stage II and III breast cancer. Br J Cancer 1997;75:301-305.

27 Bergh J, Wiklund T, Erikstein B, Lidbrink E, Lindman H, Malmstrom P, Kellokumpu-Lehtinen $\mathrm{P}$ Bengtsson NO, Soderlund G, Anker G, Wist E, Ottosson S, Salminen E, Ljungman P, Holte H, Nilsson J, Blomqvist C, Wilking N: Tailored fluorouracil, epirubicin, and cyclophosphamide compared with marrow-supported high-dose chemotherapy as adjuvant treatment for high-risk breast cancer: a randomised trial. Scandinavian Breast Group 9401 study. Lancet 2000;356:1384-1391. 